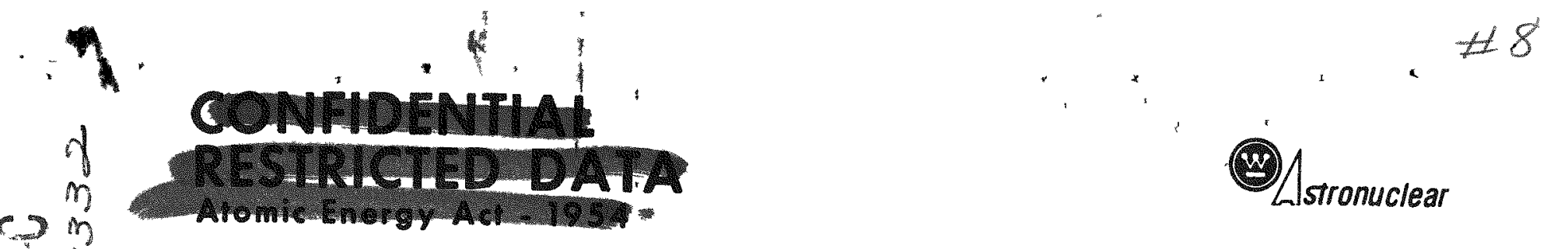

总索

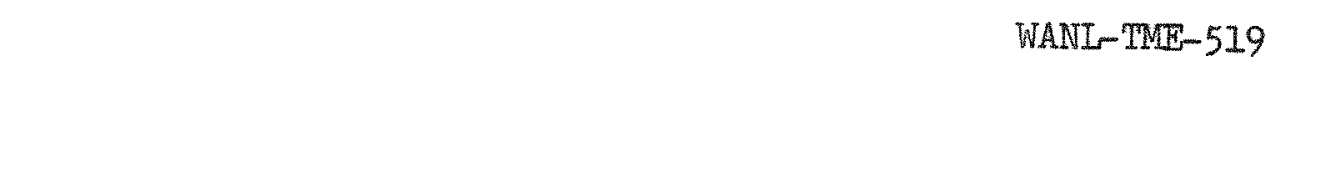

Test Series A-11/G-3

TEST REPORT ON PREIIMINARY VIBRATION DATA

BASED ON TWO SINGLE ELAMENT TEST CONFIGURATIONS

(Title Unclassified)

\section{NOTICE}

This report was prepared as an account of work sponsored by the United States Government. Nether the United States nor the United States Energy Research and Development Administration, nor any of their employees, nor any of their contractors, subcontractors, or their employees, makes any warranty, express or implied, or assumes any legal liability or responsibility for the accuracy, completeness or usefulness of any information, apparatus, product or process disclosed, or represents that its use would not infringe prvately owned rights.
Approved :
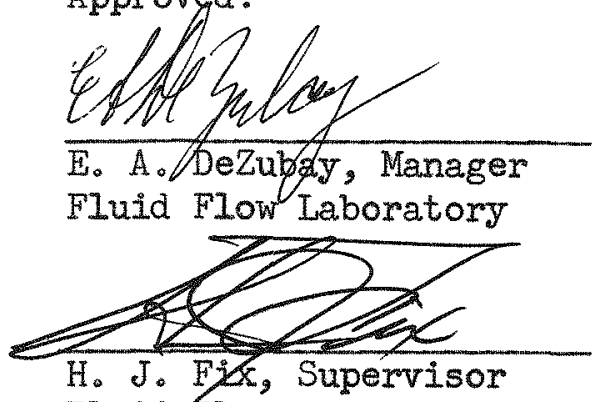

Fluid Flow Test \& Analysis

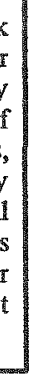

W. L. Jacob
Fluid Flow Laboratory
Experimental Fngineering

Classification cancelled lor

by by authory of 4,0 .

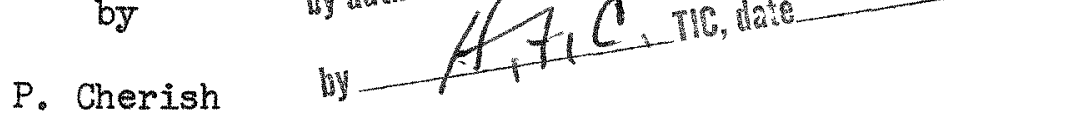

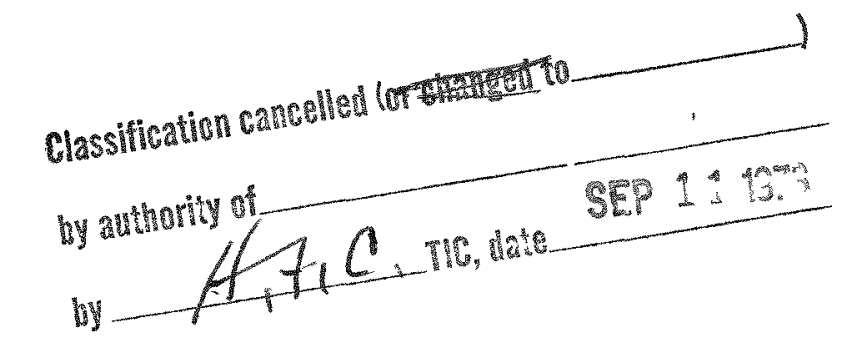

\title{
GOUP I
}

When separated from enclosures, handle

this document as UNCLASSIFIED

(Proper Classification)
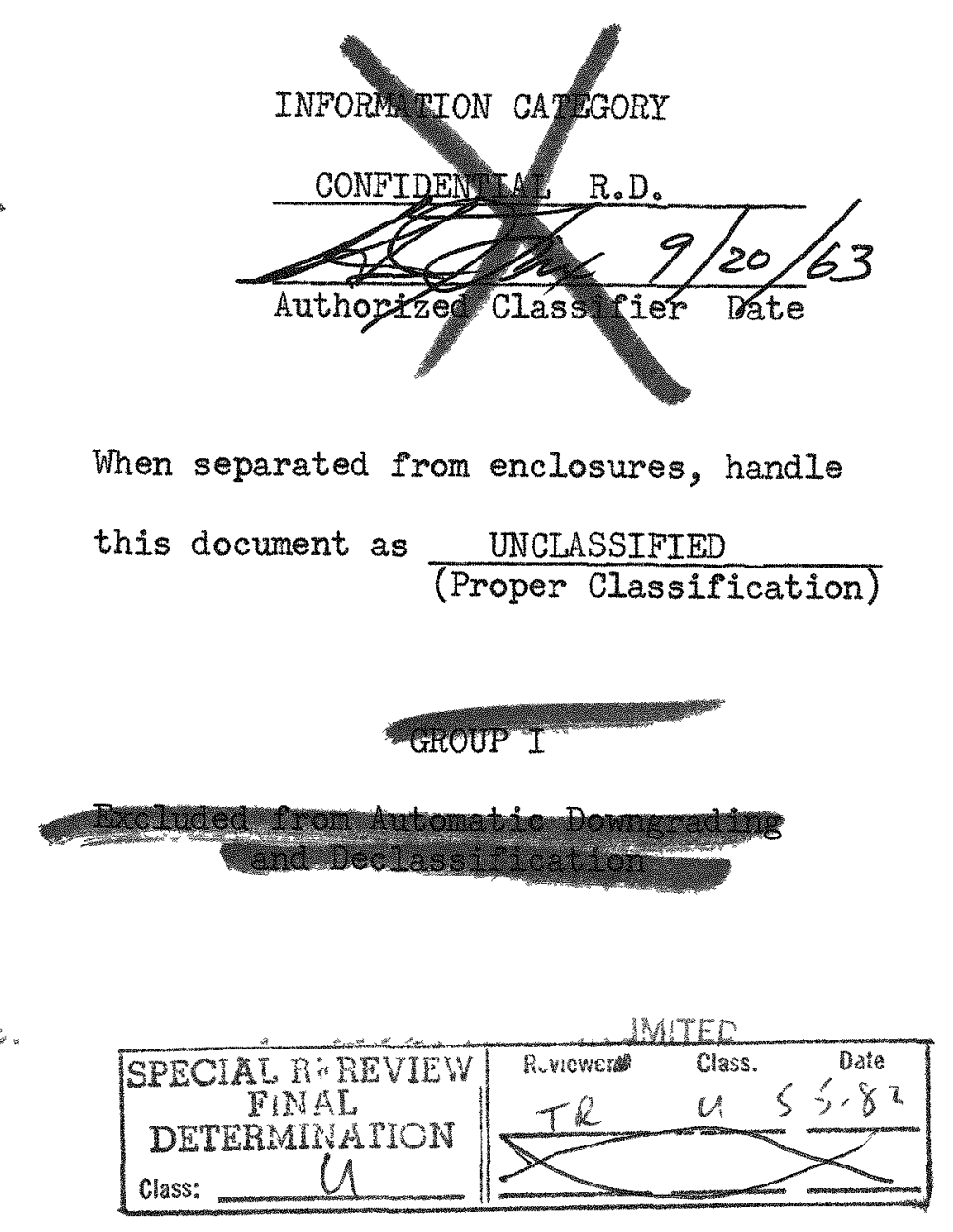


\section{DISCLAIMER}

This report was prepared as an account of work sponsored by an agency of the United States Government. Neither the United States Government nor any agency Thereof, nor any of their employees, makes any warranty, express or implied, or assumes any legal liability or responsibility for the accuracy, completeness, or usefulness of any information, apparatus, product, or process disclosed, or represents that its use would not infringe privately owned rights. Reference herein to any specific commercial product, process, or service by trade name, trademark, manufacturer, or otherwise does not necessarily constitute or imply its endorsement, recommendation, or favoring by the United States Government or any agency thereof. The views and opinions of authors expressed herein do not necessarily state or reflect those of the United States Government or any agency thereof. 


\section{DISCLAIMER}

Portions of this document may be illegible in electronic image products. Images are produced from the best available original document. 


\section{SUMMARY}

Preliminary vibration data were obtained from various tests conducted with two different types of single element test rigs to determine the behavior of the element when subjected to internal and external flow conditions.

The results from the graphite fuel element tests or internal flow tests, showed no apparent flow induced vibration at the various pressure ratios tested. In general, the damping characteristics of an externally excited element was the same for helium flow as it was for air flow. However, the rate of decay of oscillation was less for helium than for air。

The results from the simulated single element-tie rod tests, or external flow tests, showed that vibration at various frequencies could be induced by external flow around the element. The frequencies induced were found to be a function of mass flow, pressure ratio, and rod- tube clearance.

An evaluation of the results from both tests established confidence that the behavior of a fuel element is substantially the same whether plugged or unplugged when subjected to gas flow conditions. 

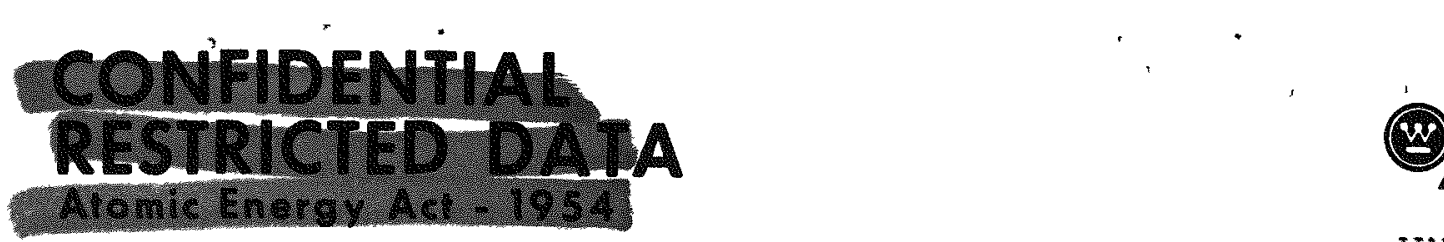

Lstronuclear

WANL-TME 519

\section{INTRODUCTION}

The single fuel element experiments reported herein are presented as a prelude to a series of component tests that are tentatively planned to be conducted under the NRX-A Component Test Program, in particular, the A-1I Flow Induced Vibration Tests, and the 63 , Plugged Core Flow Tests.

The parpose of these experiments was to establish the behavior of a single fuel element when subjected to internal and external flow.

Two series of experiments with different type single element test rigs were used to obtain the preliminary vibration data presented here.

The first series of experiments were conducted at various pressure ratios with air and helium gas at anbient temperatures flowing vertically upward through the flow passage of a cantilever mounted graphite fuel element with the gas exhausting directly to the atmosphere.

The second series of experinents were conducted at various pressure ratios with air at ambient temperstures flowing vertically upward around a simulated fuel element-tie rod confichuration mounted inside a steel tube.

The results of these experinents were used to establish that the behavior of a fuel element is substantially the same whether plugged or unplugged when subjected to gas flow conditions. 

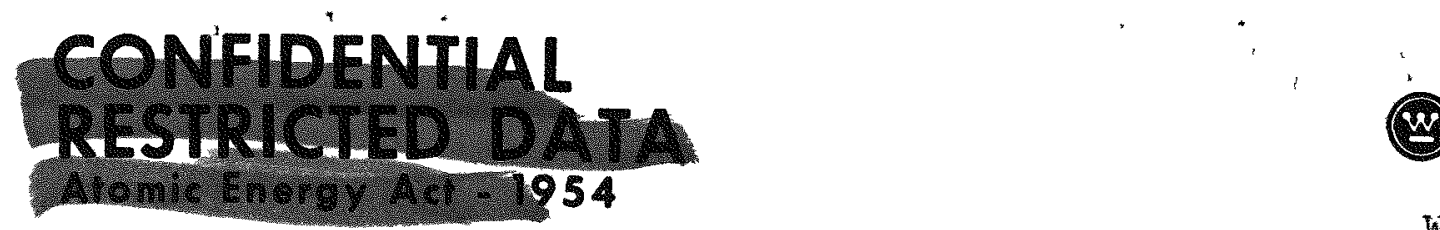

Lstronuclear

WANI-TME-519

\section{TEST APPARATUS \& INSTRUMENTATION}

\section{Graphite Fuel Element Test Rig}

The graphite fuel element test rig incorporated an unfueled niobium carbide coated graphite fuel element glued into a stainless steel holding block. One end of the element was fastened to the holding block with an epoxy adhesive (Eecobond 5I). This particular adhesive was selected because of its high shear strength (6000 psi). To utilize the high adhesion strength, the holding socket of the inlet block was serrated and the fuel element was notched on adjacent surfaces along a two-inch length. Six resistance type strain gauges were mounted on each of the six flats at the flxed end of the hexagonal element. By recording the resultant output of any of the two opposite mounted strain gauges, one of the three or all three possible modes of vibration could be measured.

A schernatic of the graphite fuel element is shown in Figure I. Figure 2 shows a schematic of the strain gauge bridge circuit. Simulated Single Element-Tie Rod Test Rig

The simulated single element-tie rod test rig incorporated 5/8" diameter aluminum rod which was made to simulate the length and approximate weight (705.5 grams) of a graphite fuel element. The aluminum rod was internally threaded on one end to adapt to a tie rod. The tie rod consisted of an externally threaded $1 / 8^{n}$ stainless steel rod which was threaded into the aluminum rod on one end and to the base of the plenum chamber on the other. The plenum chamber was made from a $3^{n}$ pipe tee, a pipe plug, and several different size reducing bushings. The aluminum rod-tie rod assembly was incased in a steel tube mounted vertically to the plenum chamber. Three, one-inch outside diameter

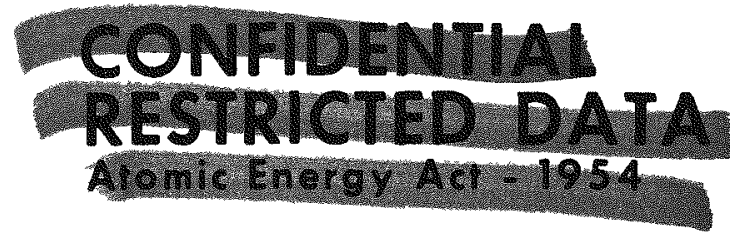



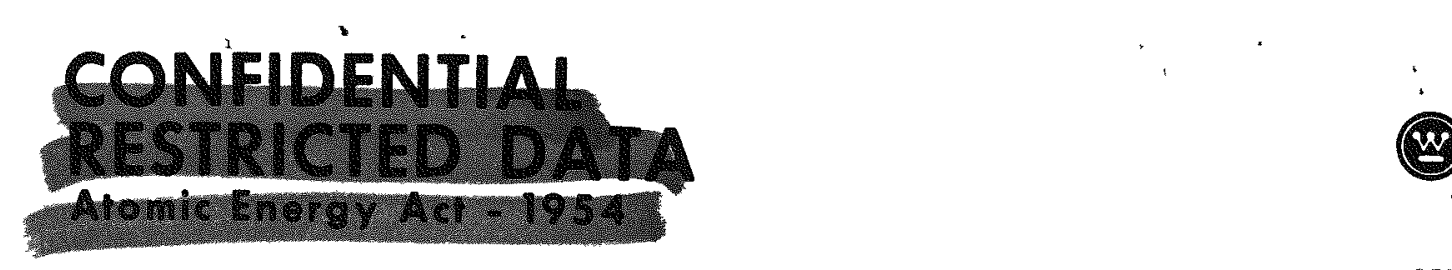

Lstronuclear

WANI-TME-519

tubes with wall thickness $.095, .120$ and .134 inches were used for the tests to obtain the various rod-tube clearance.

The test rig was instrumented with a linear variable differential transformer displacement sensor capable of measuring vibration frequencies from 0 to $300 \mathrm{cps}$. The sensor was mounted rigidly to the steel tube which was connected to the free end of the aluminum rod by a core follower attachment. Figure 3 shows a schematic of the test rig and instrumentation used for the tests. Figure 4 shows the test rig and Figure 5 shows the rig partially disassembled to show the internal components of the test rig.

\section{TEST PROCEDURE}

Graphite Fuel Element Test

Air or helium under pressure entered the vertically oriented element through the inlet plenum chamber and holding block, flowed through the passages of the element, and discharged directly to the atmosphere.

Once stable flow conditions were established at a specified inlet pressure, the output of the strain gauge bridge circuit was recorded on a Visicorder oscillograph.

To determine the damping characteristics of the fuel element under stable flow conditions, the free end of the element was purposely deflected and released to simulate external excitation.

Simulated Single Element-Tie Rod Test Rig

Air under pressure entered the plenum chamber through a flexible hose upstream of a copper tube instrumented with a total pressure probe and static pressure tap, the air flowed vertically upward between the simulated fuel element-tie rod assembly and the steel tube.

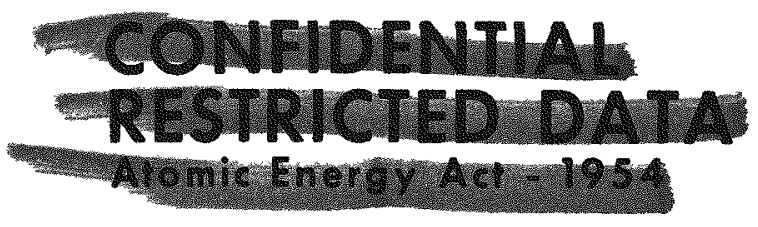




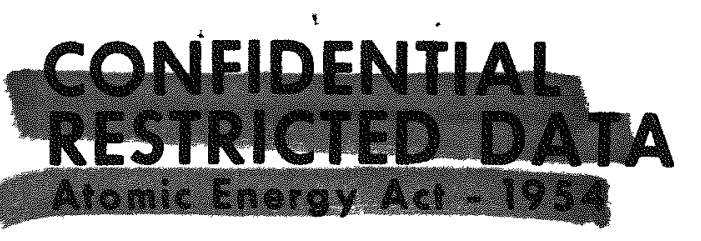

WANL-TME- 519

After stable flow conditions were established the output signal of the IVDT displacement sensor was recorded on a visicorder oscillograph. Later, tests were conducted where the output signal of the displacement gauge was recorded on an oscilloscope that was equipped with a polaroid camera attachement.

\section{DISCUSSIONS AND RESULPS}

In general, no flow induced vibration was experienced with gaseous air or helium under stable flow conditions when the gas flow was directed internally and vertically upward through the flow passages of a single graphite fuel element.

To determine the damping effect of the element under stable flow conditions, the free end of the element was purposely deflected and released. It was found that when the element was subjected to external excitation, it immediately tended to restore Itself to its original position. The damping effect experienced was similar to a viscous type damping with the rate of decay of oscillation for helium being less than air at the same pressure ratio. This type of damping effect indicates that the rate of decay is statically and dynamically stable and varies as a function of density and mass flow. Table I compares the average response time for helium and air. A typical oscillograph trace that was recorded during one of the tests with air flowing internally and upward through the passages is shown in Figure 6. The trace shows (1) the end of a steady state stable follow test with no flow induced vibration, (2) the initial deflection of the free end of the element, attempting to obtain vibration from external excitation, and (3) the damping effect of the element following the release of the free end. The rate of decay of oscillation of the element with helium and air flowing through the passages at approximately the same inlet pressure and initial deflection

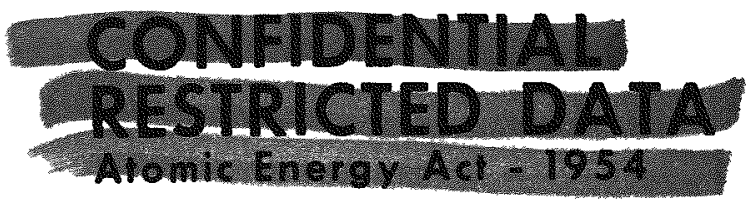



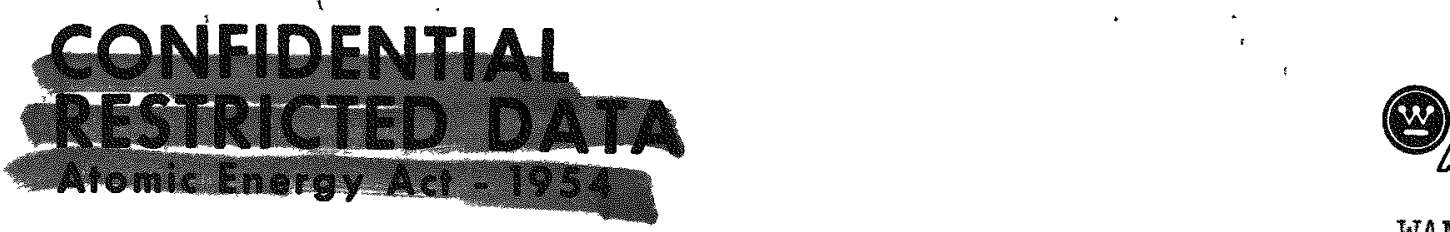

Listronuclear

WANL-TME-519

was replotted from oscillograph traces and is show in Figure 7.

Test data obtained from the simulated single element-tie rod tests showed that vibration was induced by external flow around a simulated element. The frequencies Induced were found to be function of the pressure ratio, mass flow, and rod-tube clearance. Figure 8 and 9 show the frequency ratio, measured fundamental frequency divided by the natural frequency, at various pressure ratios and mass flows for three different rodtube clearances. The measured natural frequency curve for the aluminum rod-tie rod assembly is show in Figure 10 as a function of the tie rod lengths. This frequency was obtained from oscillations in still air. Figures 11 through 14 show photographs of typical frequency traces obtained with the oscilloscope and polaroid camera attachement.

\section{CONCLUSIONS}

On the basis of the results of the various series of tests reported here, the following conclusions can be drawn:

A. Graphite Fuel Element Tests

Internal fow through the element passages does not induce vibrations. The decay time constant obtained was found to be greater for helium than for air。

B. Simulated Single Elenent-Tie Rod Tests

External flow through gaps surrounding a simulated fuel element can induce vibration. The frequency obtained was found to be a function of clearance, mass flow and, pressure ratio.

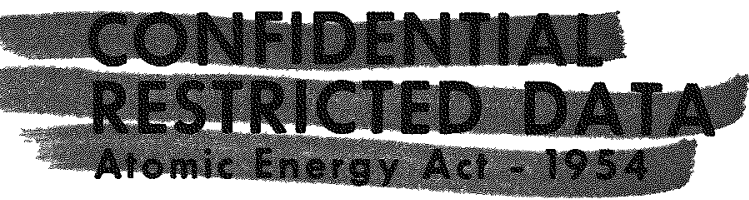




\section{CONFIDENTHA}

C. Because vibrations could not be induced by internal flow, the behavior of a plugged fuel element is not expected to be materially different than an open element. The vibration is induced by flow in the clearances between the elements as demonstrated by the external flow experiments. 


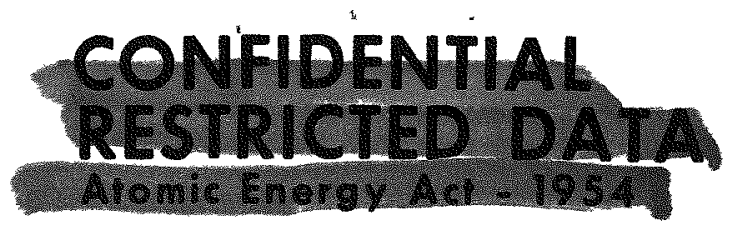

NOMENCLATURE

$\begin{array}{ll}f_{\mathrm{n}} & =\text { measured fundamental frequency } \\ f_{0} D_{0} & =\text { inside diameter } \\ \mathrm{L} & =\text { tie rod length } \\ \mathrm{i} & =\text { mass flow rate } \\ \mathrm{O}_{0} \mathrm{D}_{0} & =\text { outside diameter } \\ \mathrm{P}_{\mathrm{a}} & =\text { ambient pressure } \\ \mathrm{P}_{\mathrm{s}} & =\text { static pressure } \\ \mathrm{P}_{\mathrm{t}} & =\text { total pressure } \\ \mathrm{R} / \mathrm{T} & =\text { rod -tube clearance } \\ t & =\text { time } \\ \mathrm{W} & =\text { weight } \\ \mathrm{X}_{0} & =\text { initial deflection } \\ \mathrm{X}_{\mathrm{n}} & =\text { deflection at } \mathrm{N} \text { number of cycles } \\ T & =\text { decay time constant }\end{array}$

cps

cps

inches

inches

$1 \mathrm{~b} / \mathrm{sec}$

inches

psia

psia

psia

Inches

seconds

grams

inches

inches

seconds

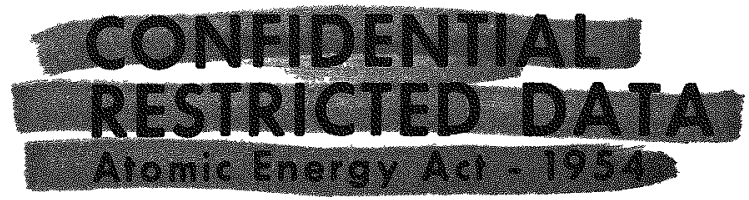

8 


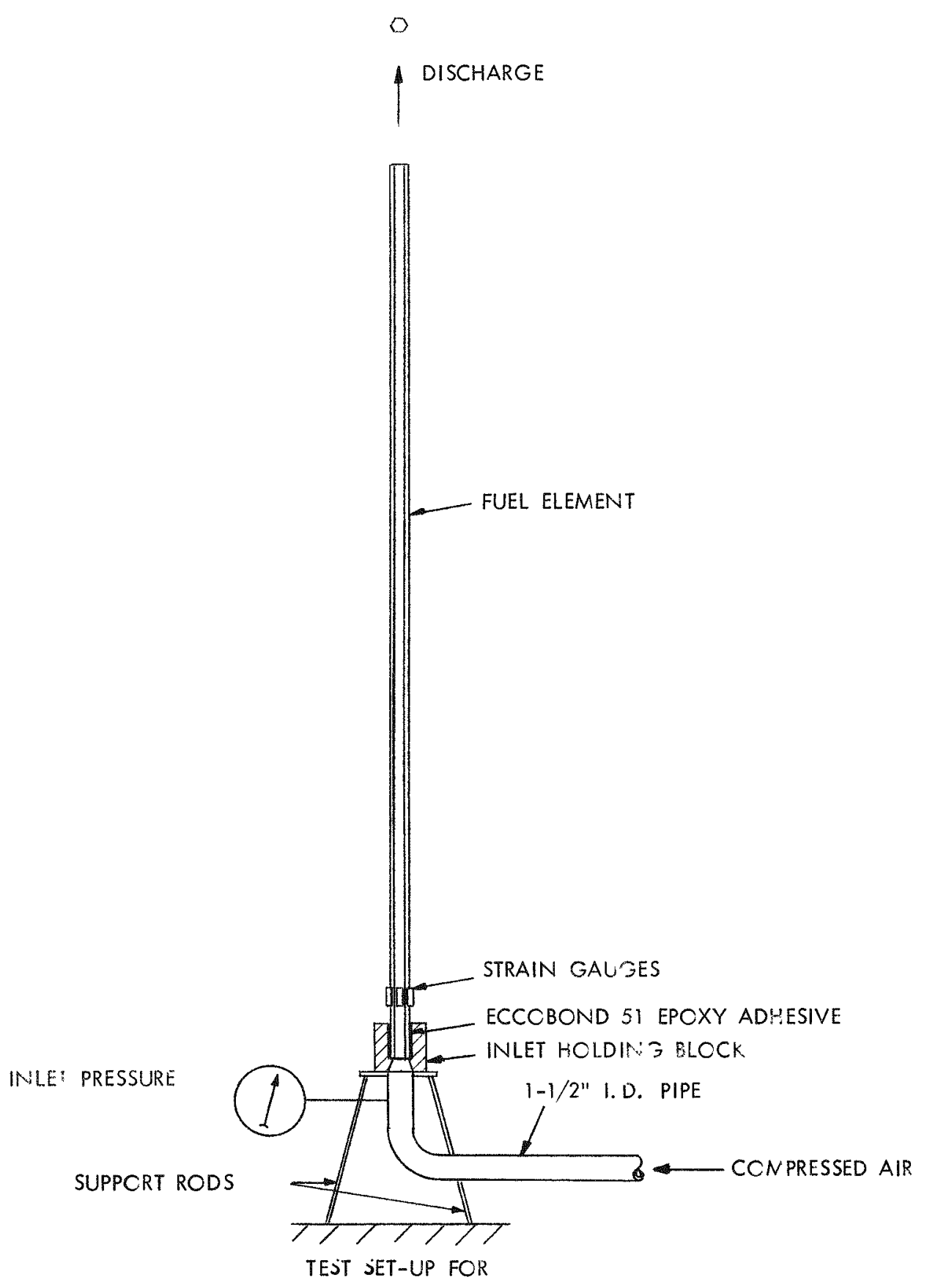

FUEL ELEMENT VIBRATION RIG

Figure 1

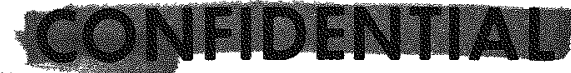



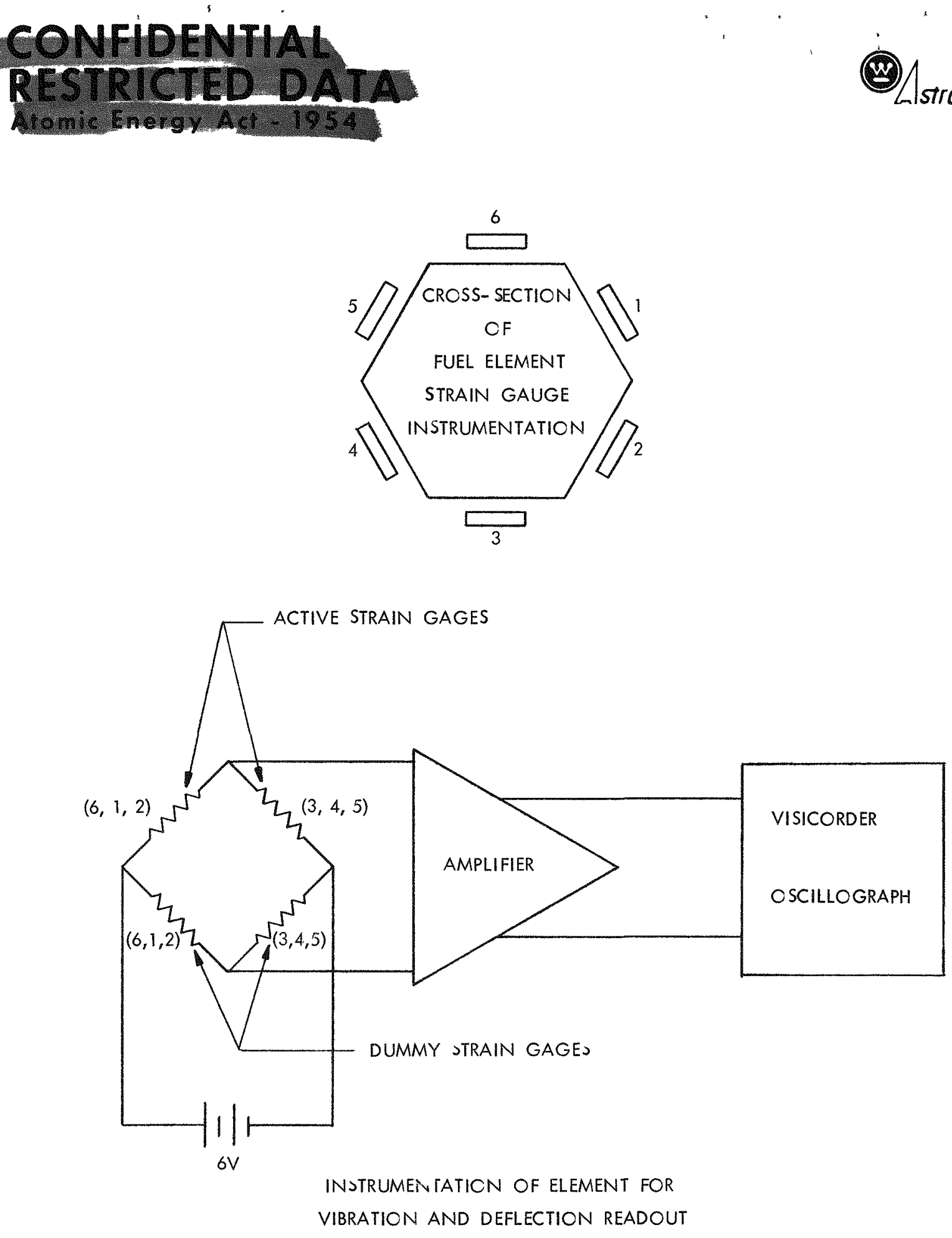

Figure 2 
SIMULATED SINGLE ELEMENT TEST RIG SCHEMATIC

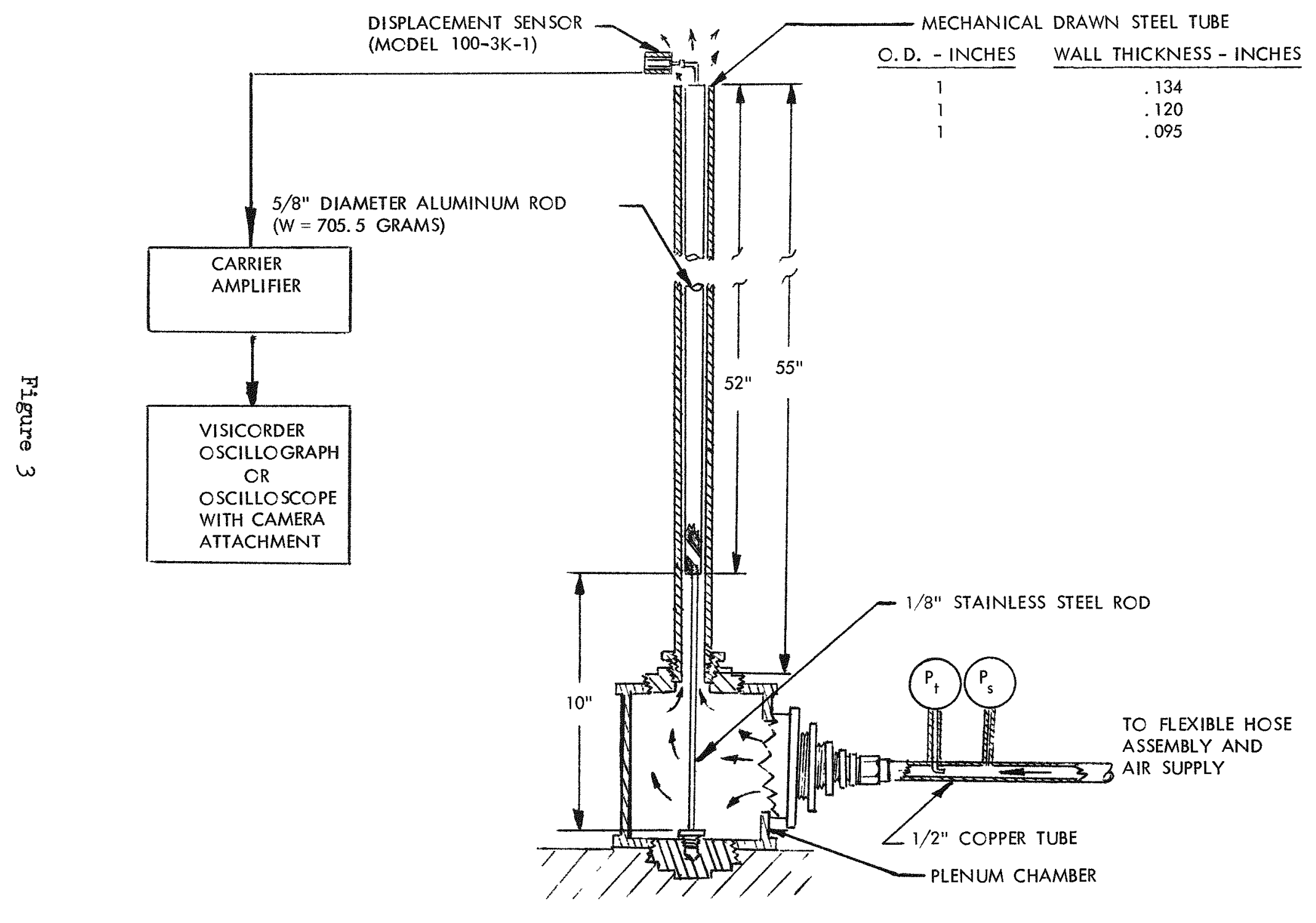




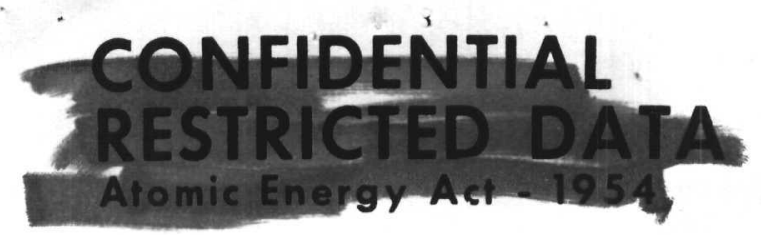

(6) Stronuclear

SIMULATED SINGLE ELEMENT TEST RIG

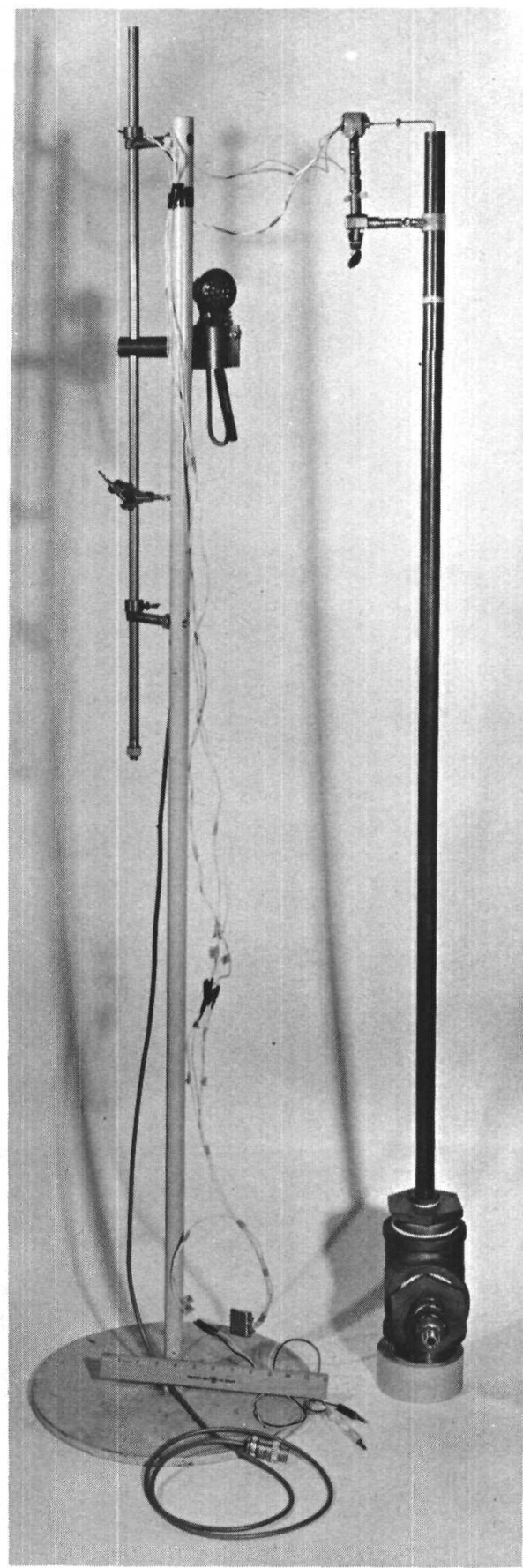

Figure 4

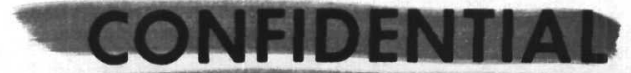




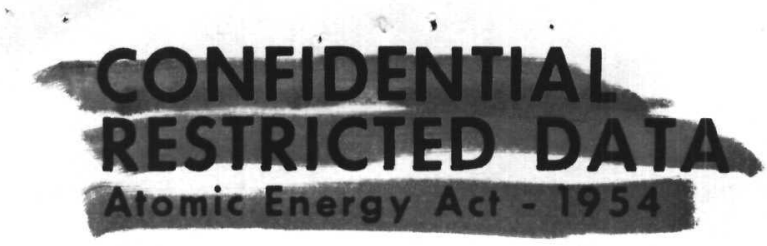

SIMULATED SINGLE ELEMENT TEST RIG PARTIALLY DISASSEMBLED

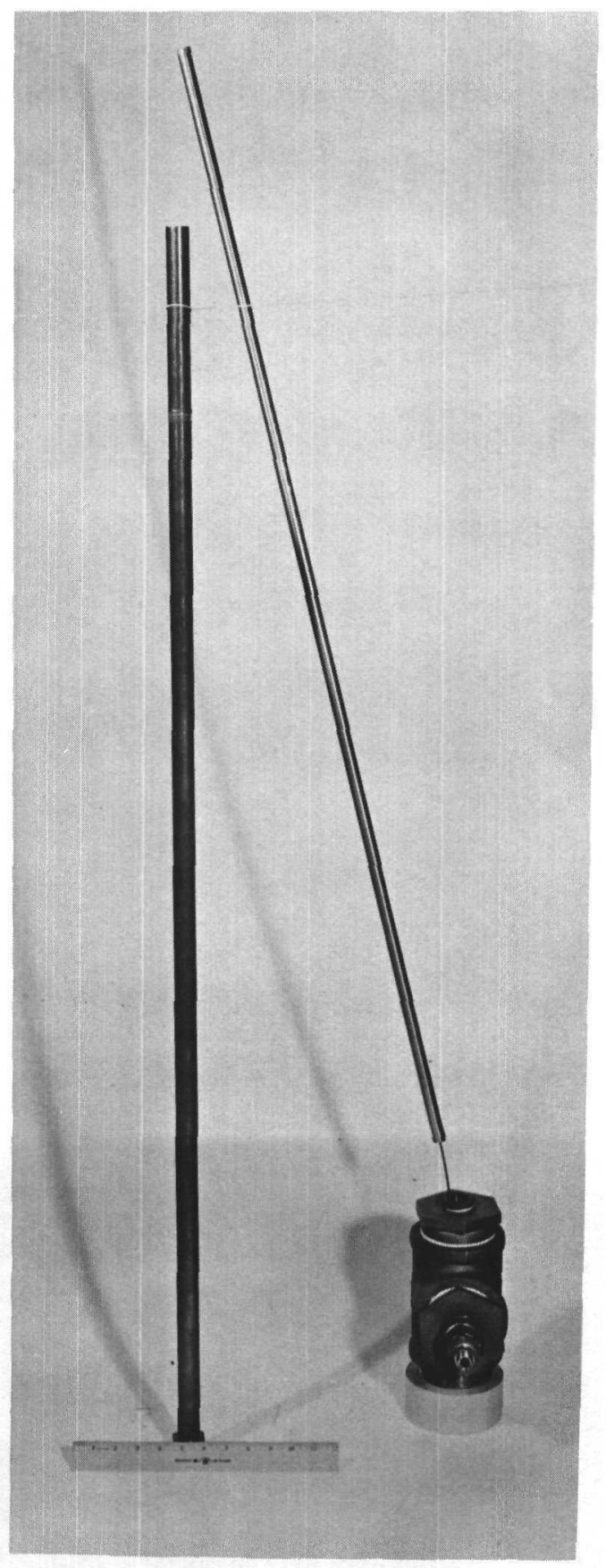

Figure 5 
A TYPICAL OSCILLOGRAPH TRACE SHOWING THE DAMPING EFFECTS OF A GRAPHITE FUEL ELEMENT WHEN SUBJECTED TO EXTERNAL EXCITATION FLUID: AIR PRESSURE RATIO: 6.5
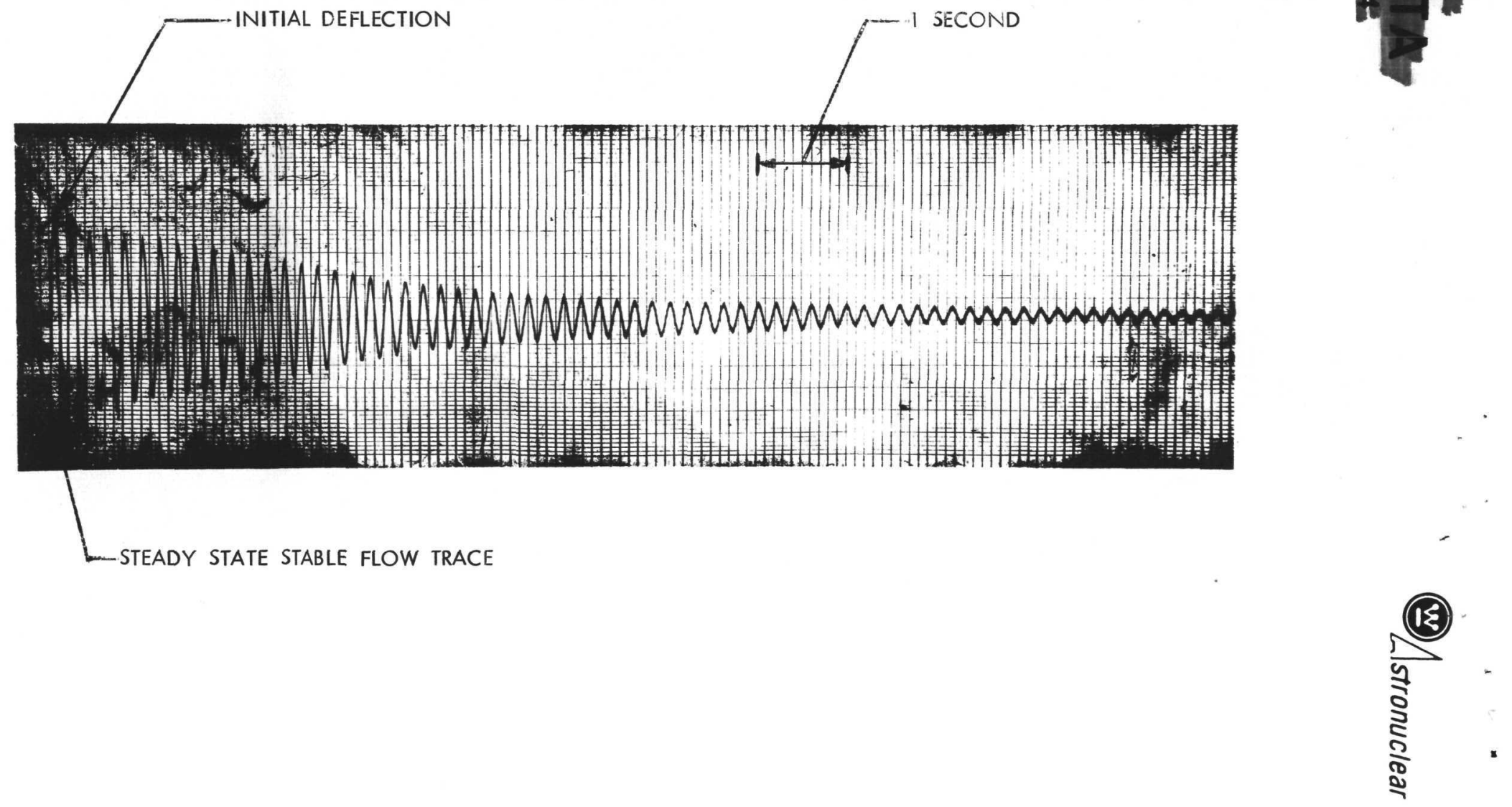
TABLE I

RATE OF DECAY OF OSCILTATION OF A

STNGLE ELEMENT SUPPORTED AT ONE END

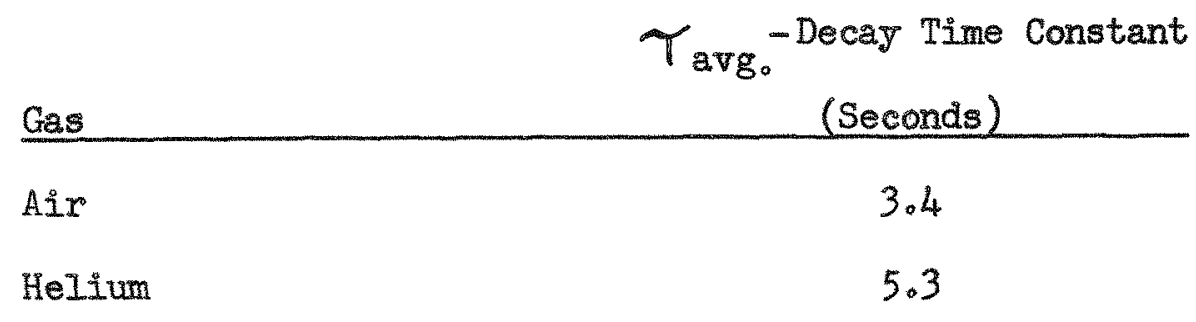

T - Time for the amplitude of the Initial deflection to decrease by 63 per cent

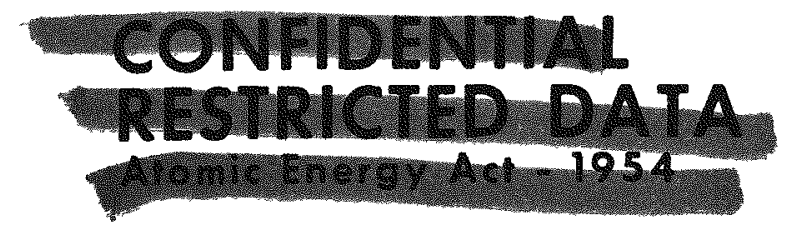


COMPARISON SHOWING THE RATE OF DECAY OF OSCILLATION OF A GRAPHITE FUEL ELEMENT WITH INTERNAL GAS FLOW

INLET PRESSURE:

48 PSIA

INITIAL DEFLECTION:

$1 / 2 \mathrm{INCH}$

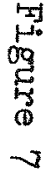

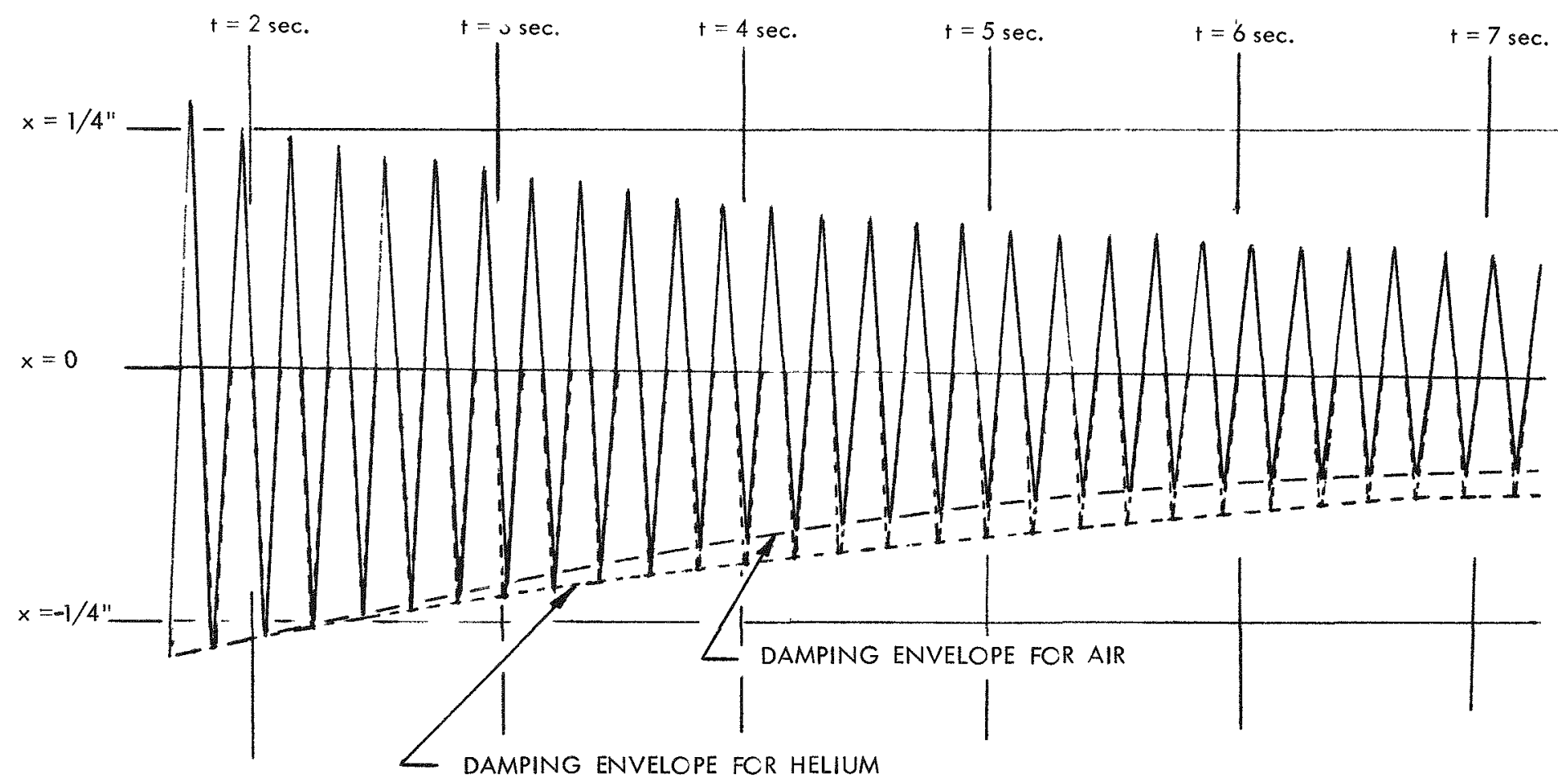


FREQUENCY RATIO VERSUS PRESSURE RATIO

FOR DIFFERENT ROD-TUBE CLEARANCE

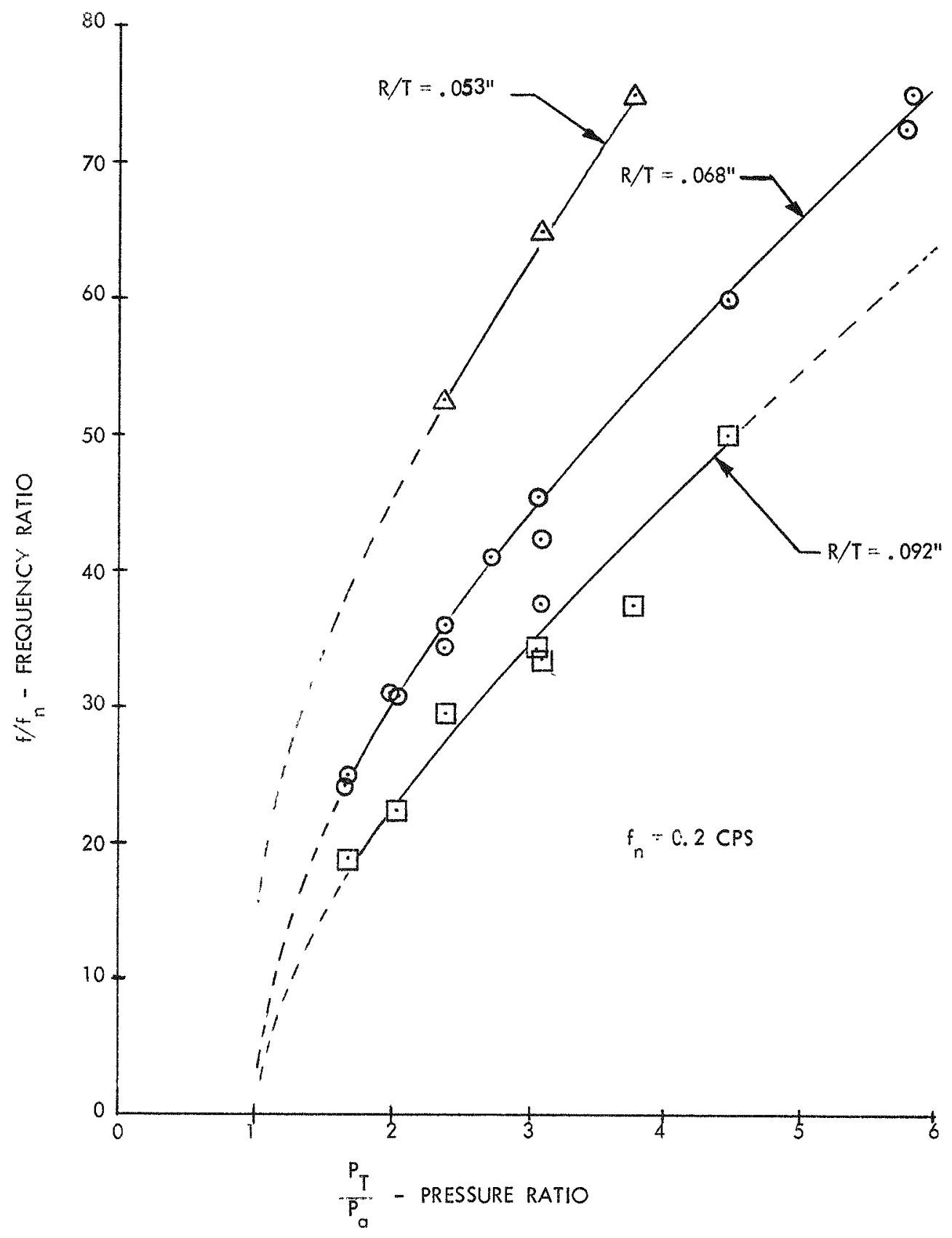

Figure 8 
FREQUENCY RATIO VERSUS AIRFLOW THROUGH A

SIMULATED SINGLE ELEMENT TEST CONFIGURATION AT DIFFERENT ROD-TUBE CLEARANCE

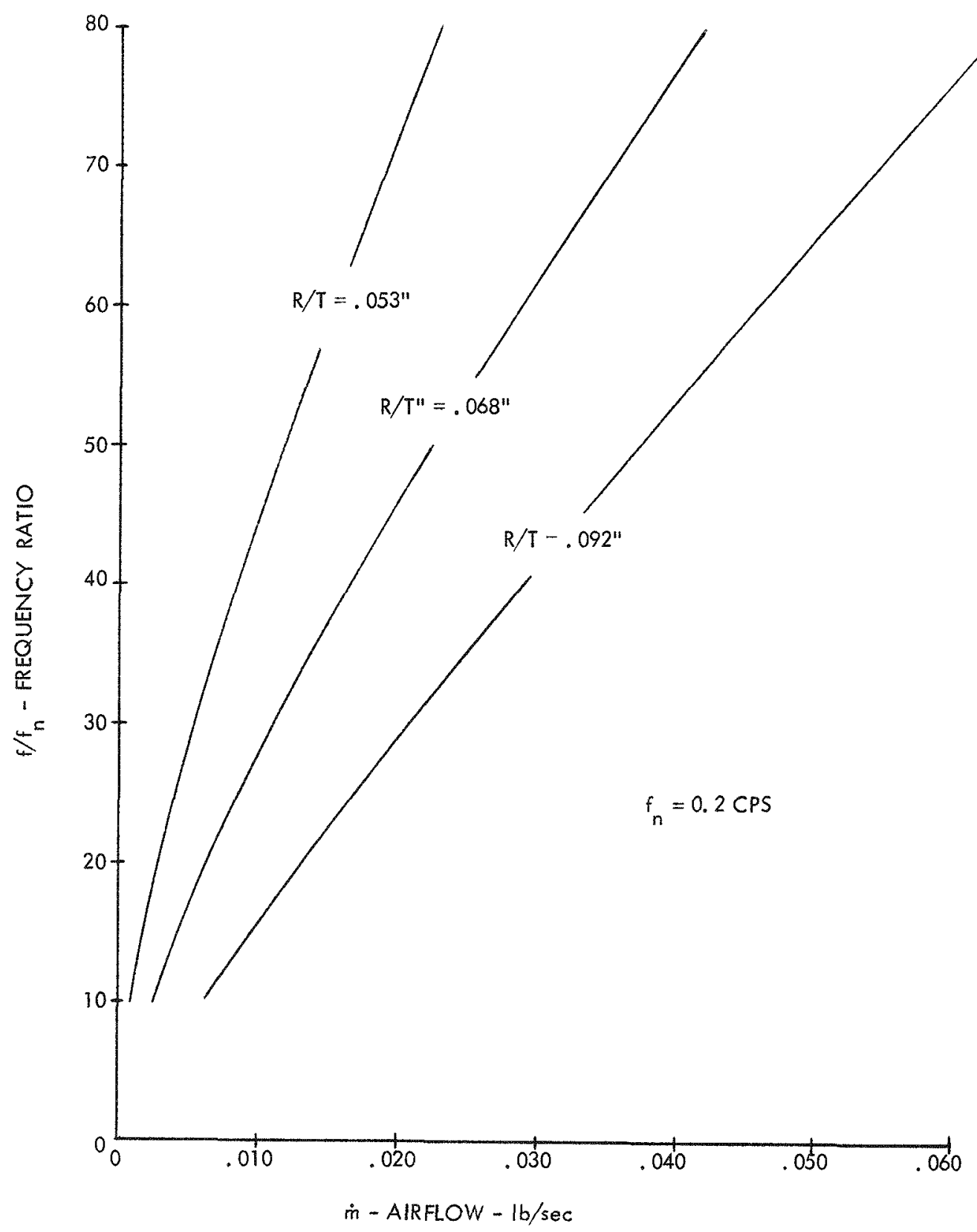

Figure 9

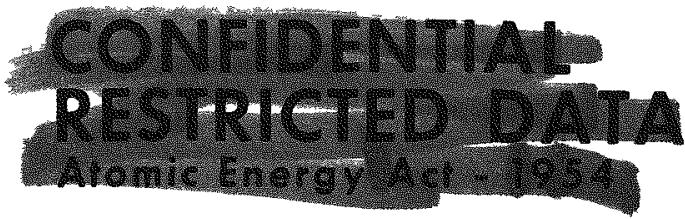


MEASURED NATURAL FREQUENCY OF AN ALUMINUM ROD-TIE ROD CONFIGURATION SUPPORTED AT VARIOUS TIE ROD LENGTHS

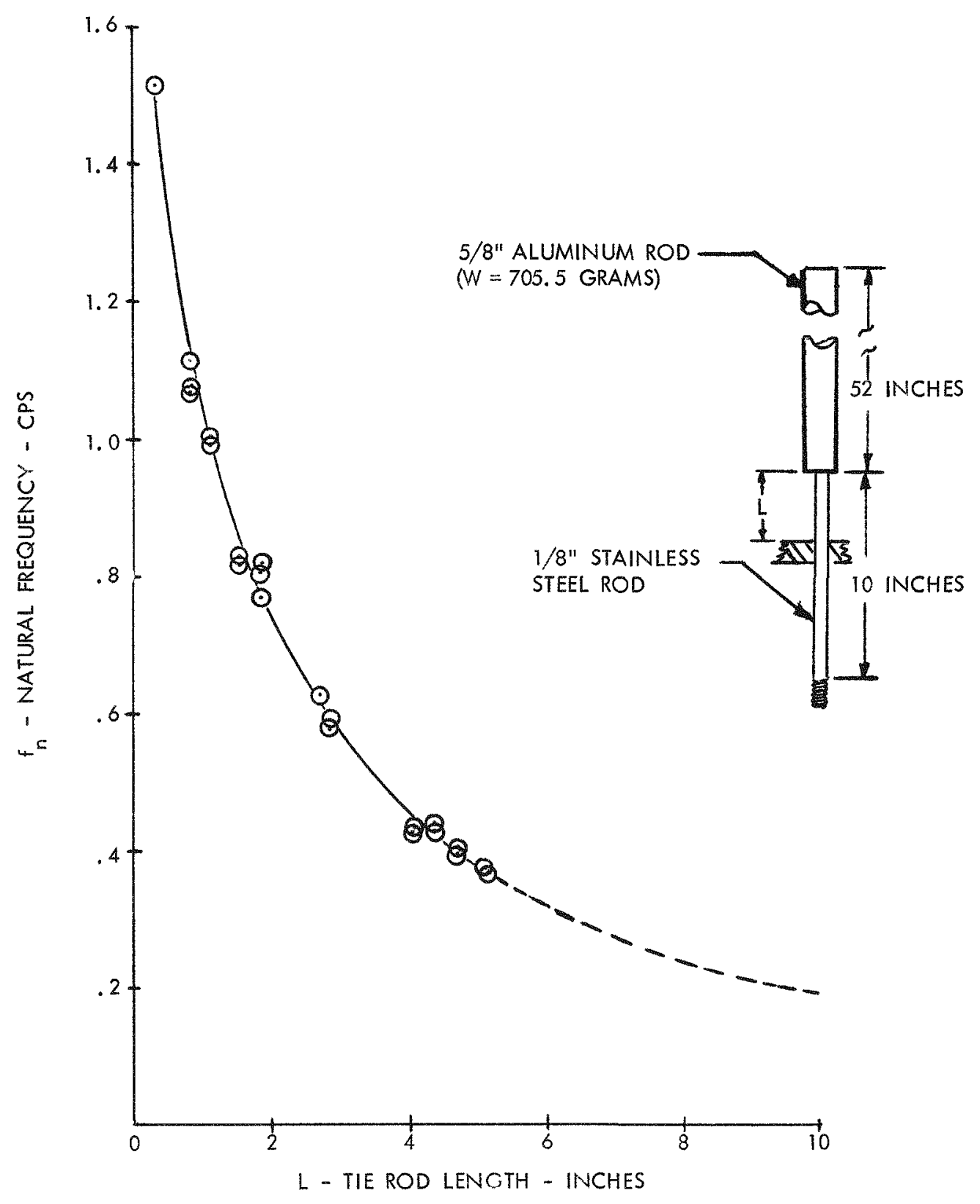

Figure 10 


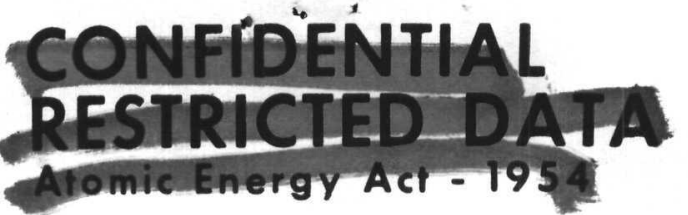

Fluid:

Primary Rod Diameter:

Weight of Rod:

Air

5/8" (Aluminum

705.5 grams
$<$

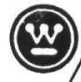

stronuclear
TEST

$A-(R-1)-11$

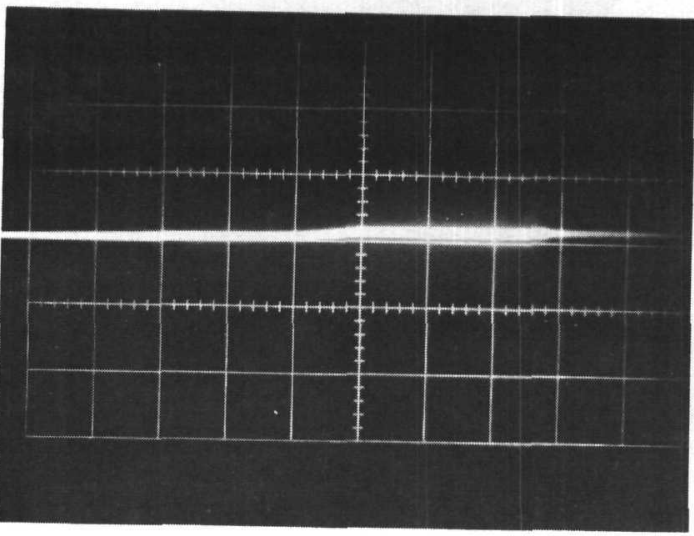

Tie Rod Diameter: Support Tube Diameter: Rod Tube Clearance:
1/8" Stainless Steel

1. 000" O. D. , 0.7601. D.

$0.068^{\prime \prime}$
Prèssure Rałio:

1.000

$f=\frac{0}{\text { Horiz. Sweep: }}$ cps

$\begin{array}{ll}\text { Horiz. Sweep: } & \frac{0.1}{0.2} \mathrm{sec} / \mathrm{cm} \\ \text { Vert. Sweep: } & \frac{0 . \mathrm{ts} / \mathrm{cm}}{1 \mathrm{sec} .}\end{array}$

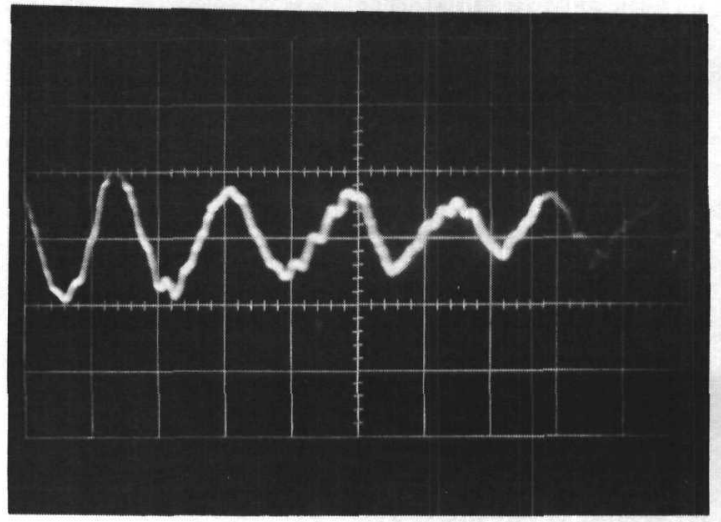

Pressure Ratio:

2. 04

$f=\frac{6.16}{\text { Horiz. Sweep }}$

$\begin{array}{ll}\text { Horiz. Sweep: } & \frac{0.1}{0.5} \mathrm{sec} / \mathrm{cm} \\ \text { Vert. Sweep: } & \text { vols } / \mathrm{cm}\end{array}$

Camera Speed:

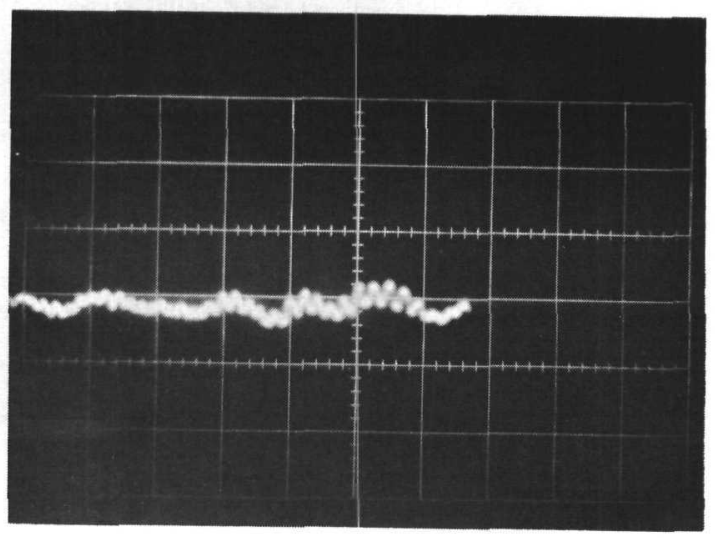

Pressure Ratio:

1. 69

$f=4.88 \mathrm{cps}$

Horiz. Sweep: $0.1 \mathrm{sec} / \mathrm{cm}$

Vert. Sweep: $-\frac{0.1}{1}$ volts $/ \mathrm{cm}$

Camera Speed: 1 sec.

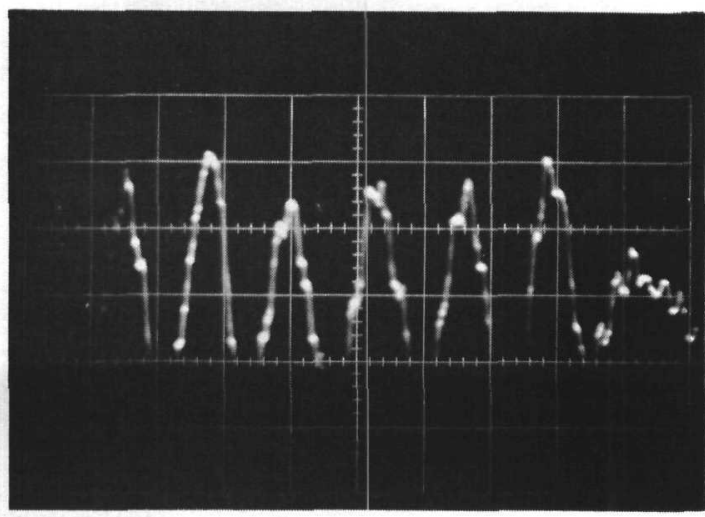

Pressure Ratio

2. 38

$f=6.85 \mathrm{cps}$

Horiz. Sweep:

Vert. Sweep:

$\frac{0.1}{\frac{0.2}{1 \mathrm{sec}} \mathrm{sec} / \mathrm{cm}} \mathrm{vol} / \mathrm{cm}$


Fluid:

Primary Rod Diameter: Weight of Rod:

Air

5/8" (Aluminum) 705.5 grams

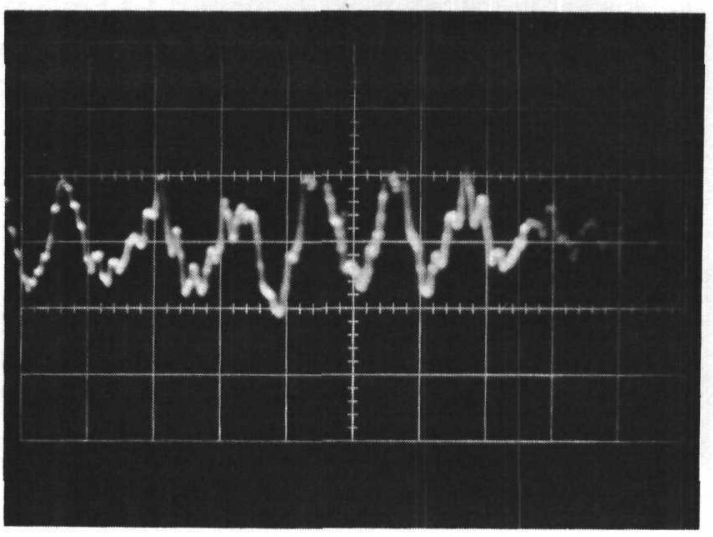

Pressure Ratio:

2. 72

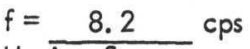

Horiz. Sweep: $0.1 \mathrm{sec} / \mathrm{cm}$

Vert. Sweep: $\frac{0.2}{1}$ volts $/ \mathrm{cm}$
Tie Rod Diameter:

Support Tube Diameter:

Rod Tube Clearance:
1/8" Stainless Steel

1.000" O. D. , 0.760I. D. $0.068^{\prime \prime}$

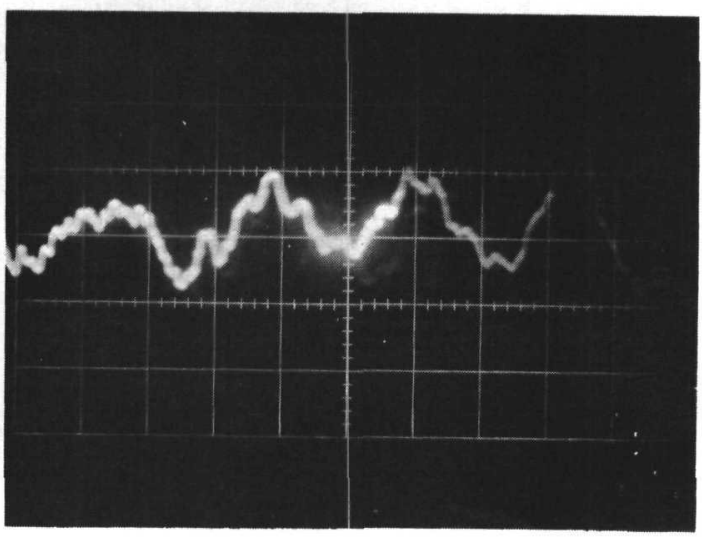

Pressure Ratio: $\quad 3.07$

$f=8.45 \mathrm{cps}$

Horiz. Sweep: $50 \mathrm{sec} / \mathrm{cm}$

Vert. Sweep: 0.2 volts $/ \mathrm{cm}$

Camera Speed: $0.5 \mathrm{sec}$. 
Fluid:

Primary Rod Diameter: Weight of Rod:
Air

5/8" (Aluminum) 705.5 grams
Tie Rod Diameter:

Support Tube Diameter:

Rod Tube Clearance:
1/8" Stainless Steel

1.000" O.D.,.810 I. D.

$0.092^{\prime \prime}$

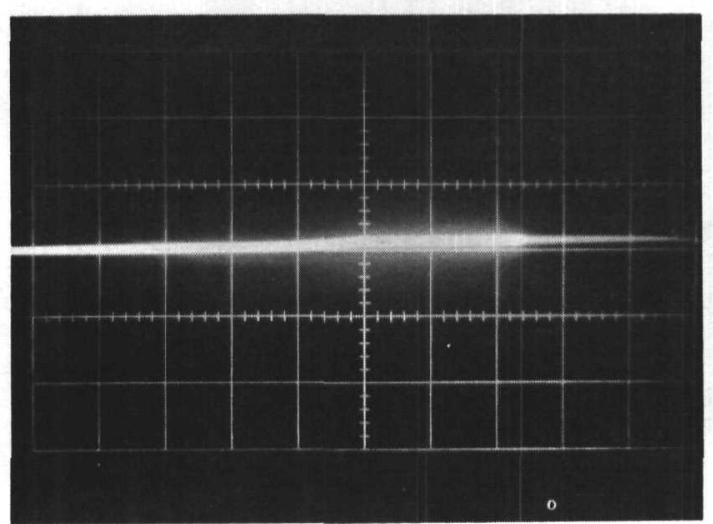

Pressure Ratio:

1. 000

$f=\frac{0}{\text { cps }}$

Camera Speed:

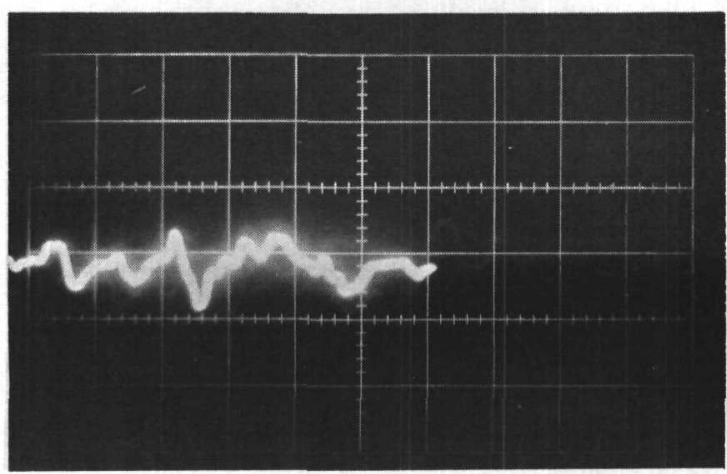

$\mathrm{sec} / \mathrm{cm}$

volts $/ \mathrm{cm}$
1 sec.

(1)
Horiz. Sweep: $\frac{0.1}{0.2}$
Pressure Ratio:

$f=\frac{4.54}{\mathrm{cps}}$

Vert. Sweep: $\frac{0.1}{0.2}$ vol ts $/ \mathrm{cm}$
Horiz. Sweep: $0.1 \mathrm{sec} / \mathrm{cm}$
2. 04

1 sec.

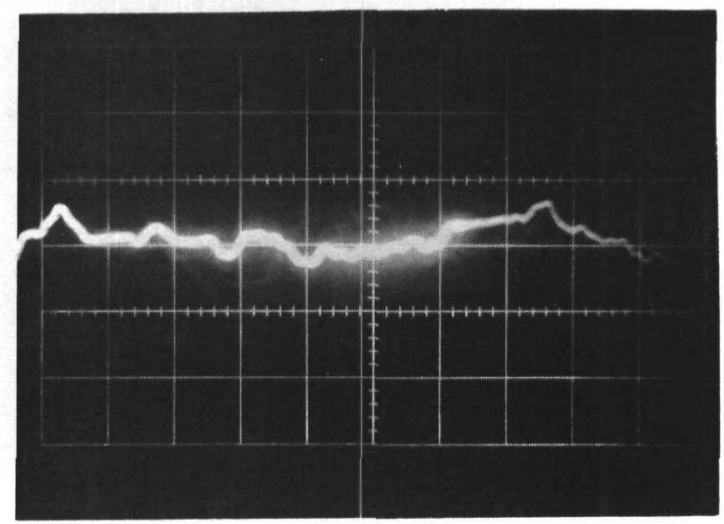

Pressure Ratio:

1.69

$f=3.78 \quad$ cps

Horiz. Sweep: $0.1 \mathrm{sec} / \mathrm{cm}$

Vert. Sweep: 0.2 vol ts $/ \mathrm{cm}$

Camera Speed: 1 sec.

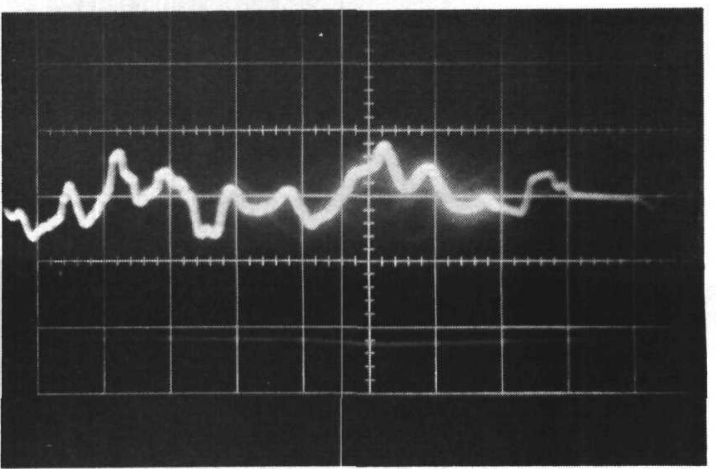

Pressure Ratio:

2. 38

$f=5.87$ cps

Horiz. Sweep: $0.1 \mathrm{sec} / \mathrm{cm}$

Vert. Sweep: 0.2 vol ts $/ \mathrm{cm}$

Camera Speed: 


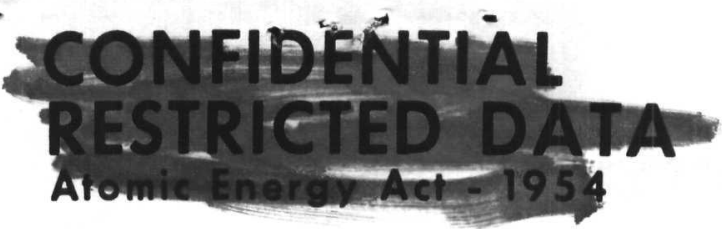

Fluid:

Primary Rod Diameter:

Weight of Rod:

Air

5/8" (Aluminum)

705.5 grams
TEST

$C-(R-1)-1$
Tie Rod Diameter: $\quad 1 / 8$ " Stainless Steel

Support Tube Diameter: $\quad$ 1.000" O. D. ,.810 I.D.

Rod Tube Clearance:
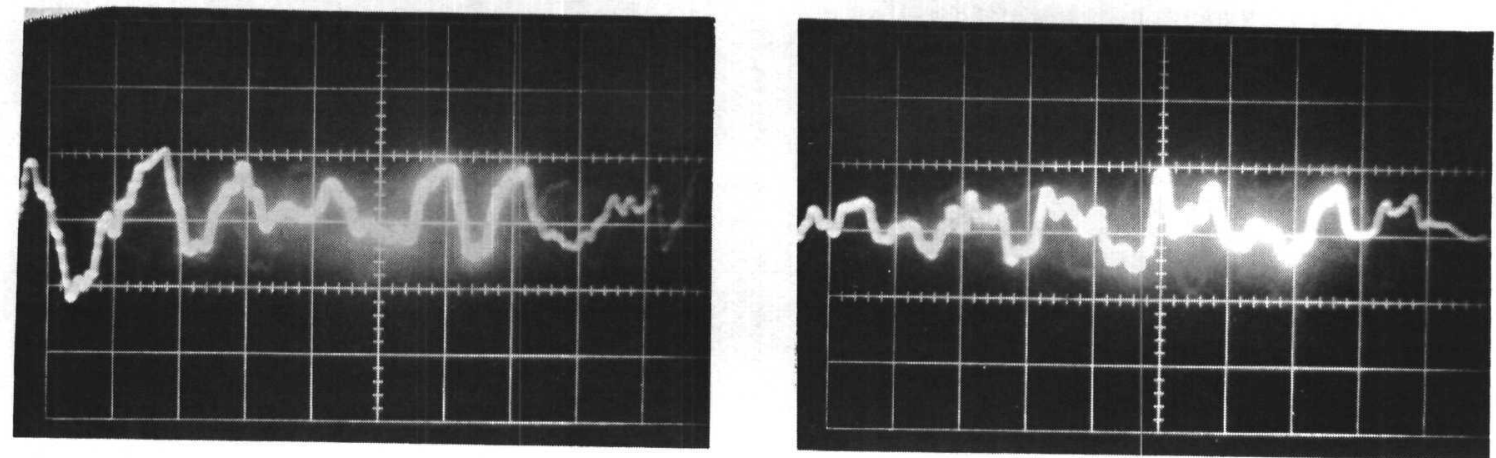

Pressure Ratio: $\quad 3.06$

$f=6.75 \mathrm{cps}$

Horiz. Sweep: $0.1 \mathrm{sec} / \mathrm{cm}$

Vert. Sweep: $\frac{0.1}{0.2}$ volts $/ \mathrm{cm}$

Camera Speed: $\frac{0.2}{1 \mathrm{sec} .}$

Pressure Ratio:

3.41

$f=7.15$ cps

Horiz. Sweep: $0.1 \mathrm{sec} / \mathrm{cm}$

Vert. Sweep: $\frac{0.1}{0.2}$ vol ts $/ \mathrm{cm}$

Camera Speed: Tsec.

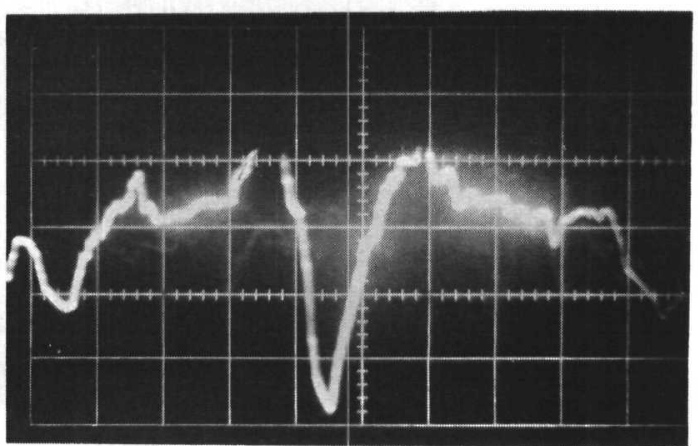

Pressure Ratio: $\quad 3.76$

$f=7.5 \mathrm{cps}$

Horiz. Sweep: 0.1

Vert. Sweep: $\frac{0.1}{0.2}$

Camera Speed: $1 \mathrm{sec}$. $\mathrm{sec} / \mathrm{cm}$

volts $/ \mathrm{cm}$
Pressure Ratio:

4. 45

$f=10 \mathrm{cps}$

Horiz. Sweep: $0.1 \mathrm{sec} / \mathrm{cm}$

Vert. Sweep: $\frac{0.1}{0.2} \mathrm{vol} / \mathrm{cm}$

Camera Speed: 